\title{
Crangonyx pseudogracilis Bousfield, 1958 - the first alien amphipod crustacean in freshwaters of Iberian Peninsula (Portugal)
}

\author{
M. Grabowski ${ }^{(1) \star}$, M. Rachalewski ${ }^{(1,2)}, \mathrm{F}$. Banha $^{(2)}$, P. Anastacio ${ }^{(2)}$ \\ Received January 12, 2012 \\ Revised February 28, 2012 \\ Accepted March 6, 2012
}

\section{ABSTRACT}

Key-words: alien species, aquatic invasions, inland waters, Mediterranean region, Crangonyctidae, first record
Crangonyx pseudogracilis, a North American crangonyctid amphipod, was found in a stream of Santarém District (Portugal) in September 2011. It is the first record of this species from the Iberian Peninsula. Exact time, mode of introduction and distribution of $C$. pseudogracilis in the area remain unknown. So far its occurrence was reported only from several countries in north-western Europe. A short overview upon the species general distribution, ecology and invasive potential is provided.

RÉSUMÉ

Crangonyx pseudogracilis Bousfield, 1958 - le premier crustacé amphipode non-natif dans les eaux douces de la péninsule ibérique (Portugal)

Mots-clés : espèces exotiques, invasions d'espèces aquatiques, région méditerranéenne Crangonetidae, premier enregistrement
Crangonyx pseudogracilis, un amphipode crangonyctid d'Amérique du Nord, a été trouvé dans un ruisseau du district de Santarém (Portugal) en Septembre 2011. II est le premier enregistrement de cette espèce dans la péninsule ibérique. La date et le mode d'introduction et la répartition de $C$. pseudogracilis dans la région restent inconnus. Jusqu'ici, sa présence n'a été signalée que dans plusieurs pays du nord-ouest de l'Europe. Un bref aperçu sur la distribution de l'espèce, l'écologie et son potentiel invasif est fourni.

The genus Crangonyx groups nearly 50 species, of which 42 are native and primarily endemic to North America (Zhang and Holsinger, 2003; Väinölä et al., 2008). Crangonyx pseudogracilis Bousfield, 1958 has the widest geographic distribution among all congeneric species. According to Zhang and Holsinger (2003) it occurs west of the Appalachian Mountains, from the Great Lakes in the north to Louisiana and Texas in the south. Some isolated populations, very similar in morphological terms, were found also in Arizona and Nevada yet their taxonomic status remains obscure. In the native area, C. pseudogracilis inhabits a wide range of surface freshwater habitats, including among others: streams, rivers, swamps, ponds and

(1) Department of Invertebrate Zoology \& Hydrobiology, University of Lodz, Banacha 12/16, 90-237 Lodz, Poland

(2) IMAR - Centro de Mar e Ambiente and Departamento de Paisagem, Ambiente e Ordenamento, Universidade de Évora, Rua Romão Ramalho 59, 7000-671 Évora, Portugal

*Corresponding author: michalg@biol.uni.lodz.pl 


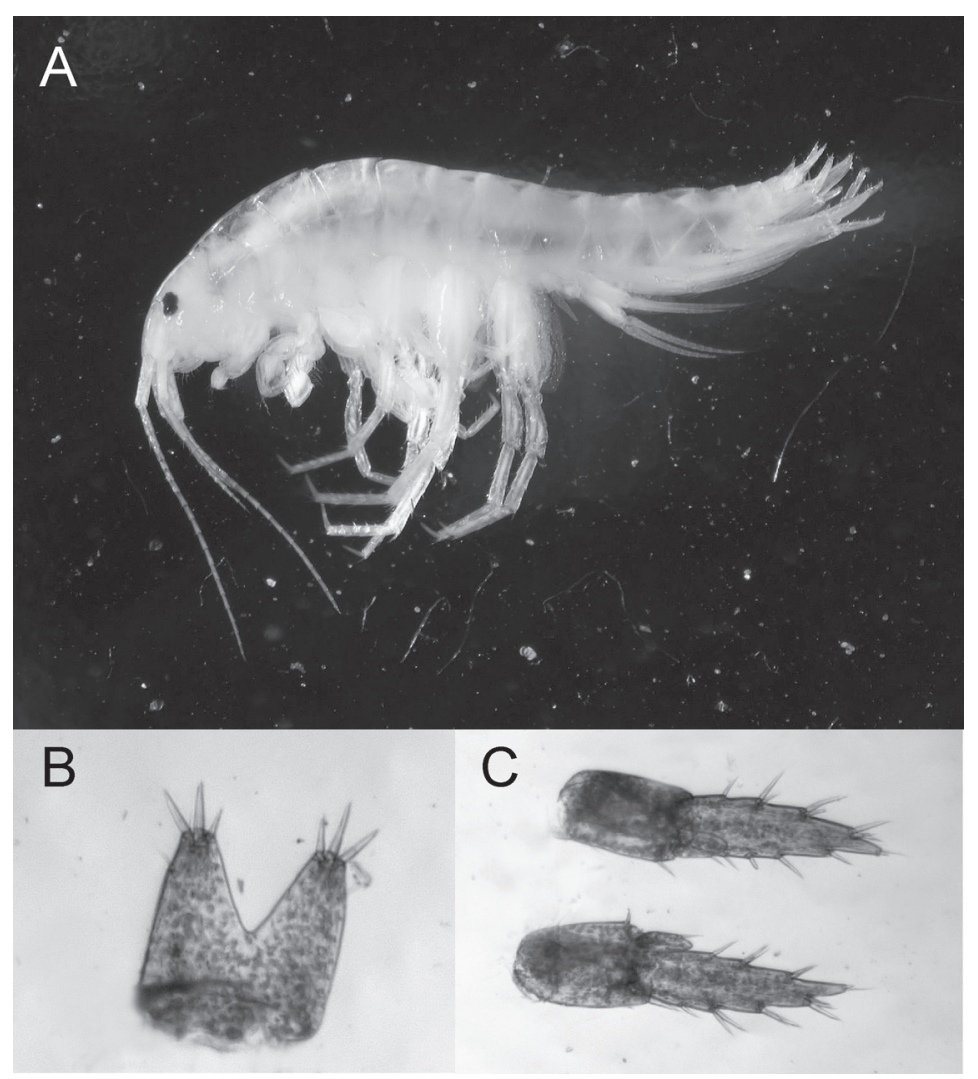

\section{Figure 1}

Crangonyx pseudogracilis found in Santarém District, Portugal. A - habitus, B - telson, C uropods III (Photographs by M. Grabowski).

lakes; a few populations are known also from caves (Holsinger, 1976; Zhang and Holsinger, 2003).

During the 1930s, Crawford (1937) and Tattersal (1937) found the species in England, in the vicinity of London, and identified it as Eucrangonyx gracilis (Smith, 1871). Until the 1990s, C. pseudogracilis has spread widely through the navigable canals in the British Islands, occurring in numerous localities in England, Wales and north-eastern Scotland (Gledhill et al., 1993). In the 1970s it was found near Dublin in Ireland (Holmes, 1975), where it has also spread, reaching Northern Ireland in the mid-1980s (Dick et al., 1999). In the late 1970s and in the 1980s it was found in the Netherlands and in Belgium (Pinkster et al., 1980; Martin, 1986). Later on, it has spread throughout north-western Europe, occurring now from the Mosel and Rhine to the German Danube; on the Scandinavian Peninsula it reaches east to Finland (Silfverberg, 1999; Tittizer et al., 2000; Bernerth and Stein, 2003; Berthold and Kaiser, 2004). Until now, the species has not been reported from Central and Eastern Europe nor from the Mediterranean region including the Iberian Peninsula. So far, nothing is known about the pathways and vectors of the species spread and introductions. Zhang and Holsinger (2003) hypothesised that it may have been introduced to Europe with ballast waters and that its spread may be related to the presence of artificial canals and transportation of live fish and/or aquatic plants.

In September and October 2011, an abundant population of C. pseugogracilis (Figure 1) was unexpectedly found by the junior authors in a small stream near the town of Granho, Santarém district, in Portugal $\left(39.096622^{\circ},-8.641719^{\circ}\right)$. The location of the sampling site is shown on Figure 2A. The sample was taken from an area of approximately $2 \mathrm{~m}^{2}$, with a benthic hand-net (equilateral triangle, $30 \mathrm{~cm}$ wide, with a $900 \mu \mathrm{m}$ mesh size), from a slowly flowing stream with muddy bottom and very rich aquatic vegetation (Figure $2 \mathrm{~B}$ ). The vegetation cover of the 


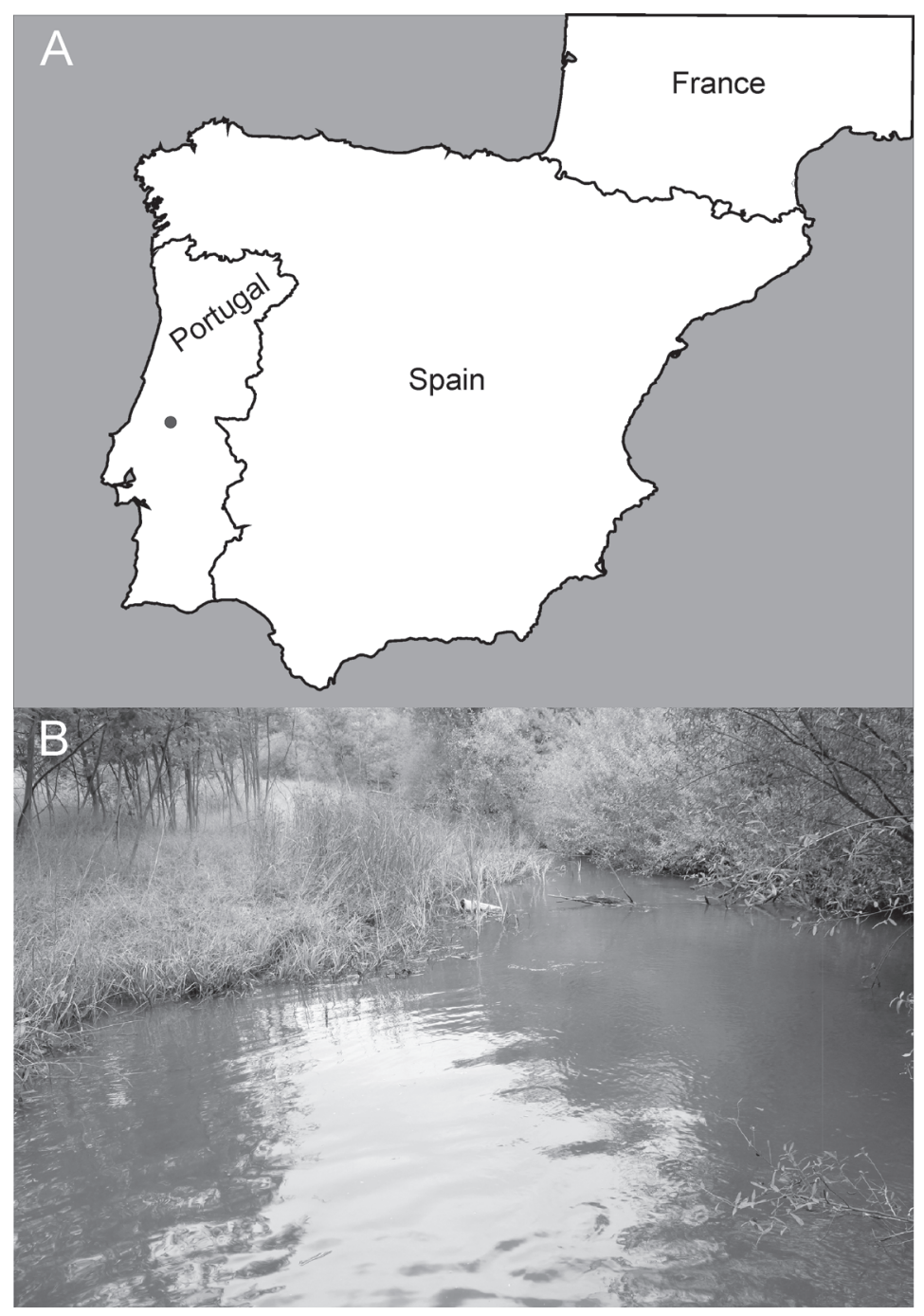

Figure 2

First record of Crangonyx pseudogracilis found in the Iberian Peninsula. A - location of the sampling site, $B$ - sampling site (Photograph by M. Rachalewski).

riverbank consisted of Cynodon dactylon and Salix atrocinerea and in the shallow water we found Cyperus longus and C. eragrostis and Scirpus lacustris. Basic physicochemical parameters of the water were measured, including temperature $\left(13.1^{\circ} \mathrm{C}\right)$, conductivity $(245$ $\left.\mu \mathrm{S} \cdot \mathrm{cm}^{-1}\right), \mathrm{pH}(6.92)$ and saturation with oxygen $\left(10.26 \mathrm{mg} \cdot \mathrm{L}^{-1}, 96.4 \%\right)$. Among the 340 individuals gathered, the majority was found among roots of Scirpus lacustris. The animals were fixed in $98 \%$ ethanol and identified to the species level, based on the features provided by Zhang and Hoslinger (2003). Crangonyx pseudogracilis was the only amphipod found at the site. The reference samples are stored in the institutional collections kept by the authors.

The conditions in which C. pseudogracilis has been found in Portugal, fit within the wide range of its habitats in Europe, that includes almost all kind of inland waterbodies, clean and polluted, fresh- or even brackish waters (Martin and Holdich, 1986; Pinkster et al., 1992). The biology of this alien crangonyctid in Europe was studied by Hynes (1955), Sutcliffe and Carrick (1981), Pinkster and Platvoet (1983) and Dick et al. (1998, 1999). According to these authors, C. pseudogracilis is reproducing throughout the year with peaks of breeding activity in spring and late summer. In opposition to gammarids, males of $C$. pseudogracilis are much smaller 
than females (respectively $3-4 \mathrm{~mm}$ and up to $11 \mathrm{~mm}$ ). Crangonyctids do not form precopulatory pairs. After copulation, eggs are laid into the broodpouch. The average brood size is 33 eggs, with a maximum of 108. Depending on temperature, the young hatch after 7 to 65 days. They reach maturity after two-three months and may live up to two years. During that time, the female is able to produce up to 8 broods. Kirkpatrick et al. (2006) suggested the use of this species as an "early warning indicator" in the Multispecies Freshwater Biomonitor (MFB) of water quality. Slothouber Galbreath et al. (2004, 2010) reported that C. pseudogracilis was introduced to Europe with its microsporidian parasite. The pathogen is vertically transmitted and has a feminizing effect on infected animals causing overproduction of female offspring. According to the above mentioned authors such manipulation may in fact promote population growth.

MacNeil et al. (1999) showed that C. pseudogracilis suffers heavy intraguild predation from European Gammarus species, due to its relatively small body size. However, mean brood size and breeding potential is higher in C. pseudogracilis than in several native European freshwater gammarids (Hynes, 1955; Pinkster et al., 1992; Guerao, 2003; Grabowski et al. 2007), which may compensate for the predation pressure. Concluding, the species has large invasive potential, particularly in warm and relatively polluted waters of the lberian Peninsula. The epigean amphipod freshwater fauna of the Iberian Peninsula has not been thoroughly studied, yet its high level of endemism is already known (Pinkster, 1993; Väinölä et al., 2008). Being the first amphipod invader in inland waters of the Iberian Peninsula, C. pseudogracilis may pose a serious threat to local species, such as Echinogammarus lusitanus (Schellenberg, 1943) or E. meridionalis Pinkster, 1973 - endemics occurring in Portuguese lowland streams (Pinkster, 1993). Thus, further studies upon the species dispersal ability, ecology, interaction with local amphipods and other freshwater macroinvertebrates are highly required.

\section{REFERENCES}

Bernerth H. and Stein S., 2003. Crangonyx pseudogracilis und Corophium robustum (Amphipoda) zwei neue einwanderer im hessischen main sowie erstnachweis für Deutschland von C. robustum. Lauterbornia, 48, 57-60.

Berthold E. and Kaiser I., 2004. Weitere Funde von Crangonyx pseudogracilis und Chelicocorophium robustum (Amphipoda) im Main. Lauterbornia, 50, 15-17.

Crawford GI., 1937. An amphipod, Eucrangonyx gracilis S.I. Smith, new to Britain. Nature, $139,327$.

Dick J.T.A., Faloon S.E. and Elwood R.W., 1998. Active brood care in an amphipod: influences of embryonic development, temperature and oxygen. Anim. Behav., 56, 663-672.

Dick J.T.A., MacNeil C. and Anderson R., 1999. The Distribution of Crangonyx pseudogracilis (Bousfield, 1958) (Crustacea: Amphipoda) in Northern Ireland, with Notes on Its Ecology and Behaviour. Ir. Nat. J., 26, 236-240.

Gledhill T., Sutcliffe D.W. and Williams W.D., 1993. British freshwater Crustacea Malacostraca: a key with ecological notes. Sci. Publ. Freshw. Biol. Assoc. Ambleside., 52, 1-173.

Grabowski M., Bacela K. and Konopacka A., 2007. How to be an invasive gammarid - comparison of life history traits. Hydrobiologia, 590, 75-84.

Guerao G., 2003. Some observations on the life history of the freshwater amphipod Echinogammarus longisetosus (Pinkster, 1973) (Gammaridae) from Catalonia (Spain, N Iberian peninsula). Anim. Biodivers. Conserv., 26, 31-39.

Holmes J.M.C., 1975. Crangonyx pseudogracilis Bousfield a freshwater amphipod new to Ireland. Ir. Nat. J., 18, 25.

Holsinger J.R., 1976. The freshwater amphipod crustaceans (Gammaridae) of North America, USEPA Off. Res., and Dev., Aq. Biol. Sect., Cincinnati, Ohio, 89 p.

Hynes H.B.N., 1955. The reproductive cycle of some freshwater Gammaridae. J. Anim. Ecol., 24, 352-387.

Kirkpatrick A.J., Gerhardt A., Dick J.T., Laming P. and Berges J.A., 2006. Suitability of Crangonyx pseudogracilis (Crustacea: Amphipoda) as an early warning indicator in the multispecies freshwater biomonitor. Environ. Sci. Pollut. Res. Int., 13, 242-250.

MacNeil C., Elwood R.W. and Dick J.T.A., 1999. Differential microdistributions and interspecific interactions in coexisting Gammarus and Crangonyx amphipods. Ecography, 22, 415-423. 
Martin T.R., 1986. Effects of water quality on the biology of freshwater peracarids, University of Nottingham, unpublished Ph.D. thesis.

Martin T.R. and Holdich D.M., 1986. The acute lethal toxicity of heavy metals to peracarid crustaceans (with particular reference to fresh-water asellids and gammarids). Water Res., 20, 1137-1147.

Pinkster S., 1993. A revision of the genus Echinogammarus (Stebbing, 1899) with some notes on related genera, Mem. Mus. Civ. St. Nat. Verona., Ila Serie., A, Biologica, Sezione Scienze della vita, 10 p.

Pinkster S. and Platvoet D., 1983. Further observations on the distribution and biology of two alien amphipods, Gammarus tigrinus (Sexton, 1939), and Crangonyx pseudogracilis Bousfield, 1958, in the Netherlands (Crustacea, Amphipoda). Bull. Zool. Mus., Univ. Amst., 9, 153-164.

Pinkster S., Dieleman J. and Platvoet D., 1980. The present position of Gammarus tigrinus Sexton, 1939, in the Netherlands, with the description of a newly discovered amphipod species, Crangonyx pseudogracilis (Bousfield, 1958) (Crustacea, Amphipoda). Bull. Zool. Mus., Univ. Amst., 7, 33-45.

Pinkster S., Scheepmaker M., Platvoet D. and Broodbakker N., 1992. Drastic changes in the amphipod fauna (Crustacea) of Dutch inland waters during the last 25 years. Bijdr. Dierkd., 61, 193-204.

Silfverberg H., 1999. A provisional list of Finnish Crustacea. Memoranda Soc. Fauna Flora Fennica, 75 , 15-37.

Slothouber Galbreath J., Smith J.E., Terry R.S., Becnel J.J. and Dunn A.M., 2004. Invasion success of Fibrillanosema crangonycis, n. sp., n.g., a novel vertically transmitted microsporidian parasite from the invasive amphipod host Crangonyx pseudogracilis. Int. J. Parasitol., 34, 235-244.

Slothouber Galbreath J., Smith J.E., Becnel J.J., Butlin R.K. and Dunn A.M., 2010. Reduction in postinvasion genetic diversity in Crangonyx pseudogracilis (Amphipoda: Crustacea): a genetic bottleneck or the work of hitchhiking vertically transmitted microparasites? Biol. Invasions, 12, 191-209.

Sutcliffe D.W. and Carrick T.R., 1981. Effect of temperature on the duration of egg development, and moulting and growth in juveniles of Crangonyx pseudogracilis (Crustacea, Amphipoda) in the laboratory. Freshw. Biol., 11, 511-522.

Tattersal W.M., 1937. Occurrence of Eucrangonyx gracilis. Nature, 139, 593.

Tittizer T., Schöll F., Banning M., Haybach A. and Schleuter M., 2000. Aquatische neozoen im makrozoobenthos der binnenwasserstraßen Deutschlands. Lauterbornia, 39, 1-72.

Väinölä R., Witt J.D.S., Grabowski M., Bradbury J.H., Jazdzewski K. and Sket B., 2008. Global diversity of amphipods (Amphipoda; Crustacea) in freshwater. In: Balian E. et al. (eds.), Freshwater animal diversity assessment. Hydrobiologia, 595, 241-255.

Zhang J. and Holsinger J.R., 2003. Systematics of the freshwater amphipod genus Crangonyx (Crangonyctidae) in North America, Memoir number 6, Virginia Museum of Natural History, Martinsville, $274 \mathrm{p}$. 